Situs Jurnal : $\underline{\text { http://ejournal.stiepancasetia.ac.id/index.php/jieb }}$

Jilid 5 Nomor 2 Juli 2019

Hal 177-190

\title{
ANALISIS PERKEMBANGAN DAN UPAYA PENINGKATAN SERTA PREDIKSI PENDAPATAN PAJAK SARANG BURUNG WALET DI KABUPATEN MURUNG RAYA
}

\section{Edy Mahfuz*}

Abstract: The main objective of this research is to study and analyze (1) The growth of wallet bird nest income in Murung Raya regency government in 2015 until 2020 (2) Efforts to increase the income of wallet bird nest tax in Murung Raya regency government analyzed by using analysis SWOT. (3) Prediction of wallet nest wall tax income in Murung Raya Regency Government 2021-2026. This research is done by quantitative method and also using the method of analysis with SWOT. The results showed that the development of wallet bird nest income income in Murung Raya district for 2015 until 2020 has increased and decreased. The prediction of wallet bird nest income tax in Murung Raya District in 2021 up to year 2026 continuously increase from year to year

\section{Keywords: Development, Enhancement, Tax Prediction}

Abstrak: Tujuan utama dalam penelitian ini adalah untuk mengkaji dan menganalisis (1) Perkembangan pendapatan pajak sarang burung wallet di pemerintah kabupaten Murung Raya tahun 2015 sampai dengan tahun 2020 (2) Upaya meningkatkan pendapatan pajak sarang burung wallet di pemerintahan Kabupaten Murung Raya yang dianalisis dengan menggunakan analisis SWOT. (3) Prediksi pendapatan pajak sarang burung wallet di Pemerintahan Kabupaten Murung Raya tahun 2021-2026. Penelitian ini dilakukan dengan metode kuantitatif serta menggunakan metode analisis dengan SWOT. Hasil penelitian menunjukan bahwa perkembangan pendapatan pajak sarang burung wallet di kabupaten Murung Raya untuk tahun 2015 sampai dengan tahun 2020 telah mengalami peningkatan dan penurunan. Prediksi pendapatan pajak sarang burung wallet di Kabupaten Murung Raya pada tahun 2021 sampai dengan tahun 2026 terus menerus mengalami peningkatan dari tahun ketahun

Kata kunci : Perkembangan, Peningkatan, Prediksi Pajak

\section{Latar Belakang}

Undang-Undang No.12 Tahun 2008 tentang Pemerintahan Daerah merupakan salah satu landasan yuridis bagi pengembangan otonomi daerah di Indonesia. Dalam Undang-undang ini disebutkan bahwa pengembangan otonomi darah diselenggarakan dengan memperhatikan prinsip-prrinsip demokrasi, peran serta masyarakat, pemerataan dan keadilan serta memperhatikan potensi dan keanekaragaman daerah. Otonomi ang diberikan Pemerintah Pusat kepada daerah dilaksanakan dengan memberikan kewenangan yang luas, nyata dan bertanggung jawab kepada Pemerintah daerah secara proporsional. Pemerintah Pusat memberikan kesempatan dan kewenangan yang sangat luas bagi pemerintah darah dalam menghimpun berbagai jenis pendapatn daerah yang konvensional yaitu dari pajak daerah dan retribusi daerah. 
Sejalan dengan kewenangan otonomi daerah tersebut pemerintah daerah diharapkan lebih mampu menggali sumber-sumber keuangan khususnya untuk memenuhi kebutuhan pembiayaan pemerintah dan pembangunan daerah melalui Pendapatan Asli Daerah (PAD), Mengingat PAD sangat penting dalam penerimaan daerah sebagai cermin kemampuan daerah dalam melaksanakan otonomi. Kemandirian daerah dalam PAD tidak hanya dalam menentukan jenis pungutan saja, tetapi daerah juga diberi keleluasaan untuk menetapakn besarnya tariff atas pungutan sehingga akan mempengaruhi pada pengalokasian anggaran dalam Dalam Anggaran Pendapatan dan Belanja Daerah.

Murung Raya merupakan salah kabupaten yang ada di Kalimantan Tengah dan ibu kota dari kota Puruk Cahu. Perekonomian Kabupaten Murung Raya tidak hanya berasal dari sektor pertambangan batu bara dan emastapi juga berasal dari sektor pertanian, perikanan dan perkebunan karet. Namun potensinya yang cukup besar akan penerimaan pajak masih belum banyak terentuh. Padahal semakin besar sumber pendapatan yang berasal dari potensi daerah dan bukan dari bantuan Pemerintah pusat, maka daerah akan semakin mampu untuk lebih mensukseskan pembangunan di daerah sesuai dengan kebutuhan masyarakatnya. Sumber pendapatan pajak daerah kabupaten Murung Raya yang masih perlu dimaksimalkan antara lain adalah pajak sarang burung walet.

Harga sarang walet di pasaran dunia sangat tinggi untuk memenuhi permintaan pasar sehingga para pengusaha sarang burung walet mulai mengembangkan usaha rumah sarang burung wallet. Berikut daftar harga sarang burung wallet.

\section{Kajian Literatur}

Pajak adalah kontribusi wajib kepada negara yang terutang oleh orang pribadi atau badan yang bersifat memaksa berdasarkan Undang-Undang, dengan tidak mendapatkan imbalan secara langsung dan digunakan untuk keperluan negara bagi sebesar-besarnya kemakmuran rakyat. (UU.KUP.psl.1.no.28.th.2007). Para ahli di bidang perpajakan mendefenisikan pajak sebagai berikut :

Menurut S.I Djajadiningrat yang ditulis oleh Siti Resmi (2007:1), menyatakan bahwa "Pajak sebagai suatu kewajiban menyerahkan sebagian dari kekayaan ke kas negara yang disebabkan suatu keadilan, kejadian dan perbuatan yang memberikan kedudukan tertentu, tetapi bukan sebagai hukuman, menurut peraturan yang ditetapkan pemerintah serta dapat dipaksakan, tetapi tidak ada jasa timbal balik dari negara secara langsung untuk memelihara kesejahteraan secara umum.

Menurut Prof. Dr. P.J.A Adriani yang telah diterjemahkan oleh R. Santoso Brotodiharjodalam buku " Pengantar Ilmu Hukum Pajak mengemukakan bahwa "pajak adalah iuran masyarakat kepada negara (yang dapat dipaksakan) yang terutang oleh yang wajib membayarnya menurut peraturan-peraturan umum (undang-undang) dengan tidak mendapat prestasi kembali yang langsung dapat ditunjuk dan digunakan untuk membiayai pengeluaranpengeluaran umum dalam menyelenggarakan pemerintahan.

Fungsi pajak sebagai alat untuk menetukan politik perekonomian, pajak memiliki kegunaan dan manfaat pokok dalam meningkatkan kesejahteraan umum. Maka, fungsi pajak tidak terlepas dari tujuan pajak, sementara tujuan pajak tidak terlepas dari tujuan Negara. Dengan demikian, tujuan pajak itu harus diselaraskan dengan tujuan Negara menjadi landasan tujuan pemerintah. Fungsi pajak terbagi menjadi dua, uraian mengenai fungsi pajak tersebut adalah sebagai berikut:

1. Fungsi Budgetair (sumber keuangan Negara) yaitu, pajak merupakan sumber dana bagi pemerintah untuk membiayai pengeluaran-pengeluaran Negara.

2. Fungsi Regulerend (mengatur) yaitu, pajak dijadikan sebagai alat mengatur dan melaksankan kebijkan pemerintah dalam bidang sosial dan ekonomi. 
Yang menjadi objek pajak adalah penghasilan, yaitu setiap tambahan kemampuan ekonomis yang diterima atau diperoleh Wajib Pajak, baik yang berasal dari Indonesia maupun dari luar Indonesia, yang dapat dipakai untuk konsumsi atau untuk menambah kekayaan Wajib Pajak yang bersangkutan, dengan nama dan dalam bentuk apa pun, termasuk beberapa hal dibawah ini:

1. Penggantian atau imbalan berkenaan dengan pekerjaan atau jasa yang diterima atau diperoleh termasuk gaji, upah, tunjangan, honorarium, komisi, bonus, gratifikasi, uang pensiun, atau imbalan dalam bentuk lainnya, kecuali ditentukan lain dalam Undang-undang ini.

2. keuntungan karena penjualan atau karena pengalihan harta.

3. penerimaan kembali pembayaran pajak yang telah dibebankan sebagai biaya dan pembayaran tambahan pengembalian pajak.

4. bunga termasuk premium, diskonto, dan imbalan karena jaminan pengembalian utang.

5. dividen, dengan nama dan dalam bentuk apapun, termasuk dividen dari perusahaan asuransi kepada pemegang polis, dan pembagian sisa hasil usaha koperasi.

6. royalti atau imbalan atas penggunaan hak.

7. sewa dan penghasilan lain sehubungan dengan penggunaan harta.

Pajak Sarang Burung Walet adalah pajak atas kegiatan pengambilan dan/atau pengusahaan sarang burung walet. Burung Walet adalah satwa yang termasuk marga collocalia, yaitu collocalia fuchliap haga (walet sarang putih), collocalia maxina (walet sarang hitam), collocalia esculanta (walet sapi), dan collocalia linchi (walet linci).

Objek Pajak Sarang Burung Walet adalah pengambilan dan/atau pengusahaan Sarang Burung Walet. Tidak termasuk objek pajak adalah:

1. pengambilan Sarang Burung Walet yang telah dikenakan Penerimaan Negara Bukan Pajak (PNBP).

2. kegiatan pengambilan dan/atau pengusahaan Sarang Burung Walet lainnya yang ditetapkan dengan Peraturan Daerah.

Ketentuan jenis PNBP yang dikecualikan sebagai Objek Pajak, dapat mengacu pada Peraturan Menteri Kehutanan Nomor P.37/Menhut-II/2014 tentang Tata Cara Pengenaan, Pemungutan Dan Penyetoran Penerimaan Negara Bukan Pajak Bidang Perlindungan Hutan Dan Konservasi Alam dengan uraian sebagai berikut:

1. Iuran Izin Usaha Pemanfaatan Tumbuhan dan Satwa Liar (IIUPTSL) adalah iuran yang dikenakan kepada pemegang izin usaha pemanfaatan tumbuhan dan satwa liar.

2. IIUPTSL meliputi iuran izin pengedar dalam negeri, iuran izin pengedar luar negeri, iuran izin penangkaran, iuran izin peragaan, iuran izin lembaga konservasi, izin pengelolaan sarang burung walet di dalam zona/blok pemanfaatan kawasan pelestarian alam, iuran izin pengusahaan taman buru, iuran akta buru di taman buru, iuran hasil buruan satwa buru dan iuran izin pengambilan sampel penelitian (mati/bagian-bagian).

Pajak Sarang Burung Walet termasuk salah satu jenis pajak daerah yang baru dapat dipungut Pemerintah Kabupaten/Kota sejak ditetapkan dalam UU No. 28 Tahun 2009 tentang Pajak Daerah dan Retribusi. Pada UU Nomor 34 Tahun 2000 tentang PDRD, jenis pajak ini belum termuat sebagai salah satu opsi pajak daerah.

Pihak yang dibebani Pajak (Subjek Pajak) Sarang Burung Walet adalah orang pribadi atau Badan yang melakukan pengambilan dan/atau mengusahakan Sarang Burung Walet. Demikian 
pula pengusaha sarang burung walet berkedudukan pula sebagai Wajib Pajak yang menyampaikan laporan omzet usaha yang akan dikenakan beban Pajak.

Dasar pengenaan Pajak Sarang Burung Walet adalah Nilai Jual Sarang Burung Walet. Nilai Jual Sarang Burung Walet dihitung berdasarkan perkalian antara harga pasaran umum Sarang Burung Walet yang berlaku di daerah yang bersangkutan dengan volume Sarang Burung Walet.

Berdasarakan Surat Pemberitahuan Pajak Daerah (SPTPD), Bupati menetapkan pajak terutang dengan menerbitkan Surat Ketetapan Pajak Daerah (SKPD). Apabila SKPD tidak atau kurang dibayar setelah lewat waktu paling lama 30 hari sejak diterimanya SKPD dikenakan sanksi administrasi berupa bunga 20\% sebulan dan ditagih dengan menerbitkan Surat Tagihan Pajak Daerah (SKPD).

SPTPD yang telah diisi oleh wajib pajak digunakan sebagai bahan untuk menghitung, memperhitungkan dan menetapkan pajak sendiri yang terutang. Dalam jangka waktu 5 tahun sesudah saat terutang pajak, bupati dapat menerbitkan Surat Ketetapan Pajak Daerah Kurang Bayar (SKPDKB), Surat Ketetapan Pajak Daerah Kurang Bayar Tambahan (SKPDKBT) dan Surat Ketetapan Pajak Daerah Nihil (SKPDN). SKPDKB diterbitkan apabila:

1. Berdasarkan hasil pemeriksaan atau keterangan lain pajak yang terutang tidak atau kurang dibayar dikenakan sanksi administrasi berupa bunga sebesar $20 \%$ sebulan dihitung dari pajak yang kurang atau terlambat bayar untuk jangka waktu paling lama 24 bulan dihitung sejak saat terutang pajak.

2. SPTPD tidak disampaikan dalam jangka waktu yang ditentukan dan telah ditegur secara tertulis, dikenakan sanksi administrasi berupa bunga sebesar $2 \%$ sebelun dihitung dari pajak yang kurang atau terlambat dibayar untuk jangka waktu paling lama 24 bulan dihitung sejak saat terutangnya pajak.

3. Kewajiban mengisi SPTPD tidak dipenuhi, pajak yang terrutang dihitung secara jabatan dan dikenakan sanksi administrasi berupa kenaikan sebesar 25\% dari pokok pajak ditambah sanksi administrasi berupa bunga sebesar $2 \%$ sebulan dihitung dari pajak yang kurang atau terlambat dibayar untuk jangka waktu paling lama 24 bulan dihitung sejak saat terutang pajak.

SKPDKBT diterbitkan apabila ditemukan data baru atau data yang semula belum terungkap yang menyebabkan penambahan jumlah pajak yang terutang, akan dikenakan sanksi administrasi berupa kenaikan 100\% dari jumlah kekurangan tersebut. SKPDN diterbitkan apabila jumlah pajak yang terutang sama besarnya dengan jumlah kredit pajak atau pajak tidak terutang dan tidak ada kredit pajak. Apabila kewajiban membayar pajak dalam SKPDKB dan SKPDKBT tidak atau tidak sepenuhnya dibayar dalam jangka waktu yang telah ditentukan, ditagih dengan menerbitkan STPD ditambah dengan sanksi administrasi berupa bunga $20 \%$ sebualn dan ditagih dengan menerbitkan STPD.

Pembayaran pajak dilakukan di kas daerah atau tempt yang ditunjuk Bupati sesuai waktu yang ditentukan dalam SKPD, SKPDKB, SKPDKBT dan STPD. Apabila pembayarn pajak yang dilakukan di tempat lain yang ditunjuk, hasil penerimaan pajak harus disetorkan ke kas daerah selambat-lambatnya 1 x 24 jam atau dalam waktu yang ditentukan oleh Bupati. Pembayaran pajak yang dilakukan dengan menggunakan Surat Setortan Pajak Daerah (SSPD). Pembayaran pajak harus dilakukan secara teratur berturut-turut dengan dikenakan bunga sebesar 2\% sebulan dari jumlah pajak yang belum atau kurang bayar.

\section{Metode Penelitian}

Penelitian yang dilakukan termasuk jenis penelitian studi kasus yaitu penelitian terhadap suatu obyek tertentu dan hasil yang diperoleh dari analisis data hanya berlaku untuk obyek 
tertentu serta dalam waktu tertentu. Objek dalam penelitian ini adalah kantor Dinas Pengelola Keuangan Daerah Kabupaten Murung Raya.

Dalam menganalisis data,penulis menggunakan teknik analisis data kuantitatif dan kualitatif sebagai berikut:

1. Untuk menjawab rumusan masalah yang pertama yaitu tentang perkembnagan pendapatan pajak sarang burung wallet selama tahun 2015 sampai dengan tahun 2020 digunakan analisis indeks berantai (Budiyuwono, 1987: 179) dengan rumus sebagai berikut:

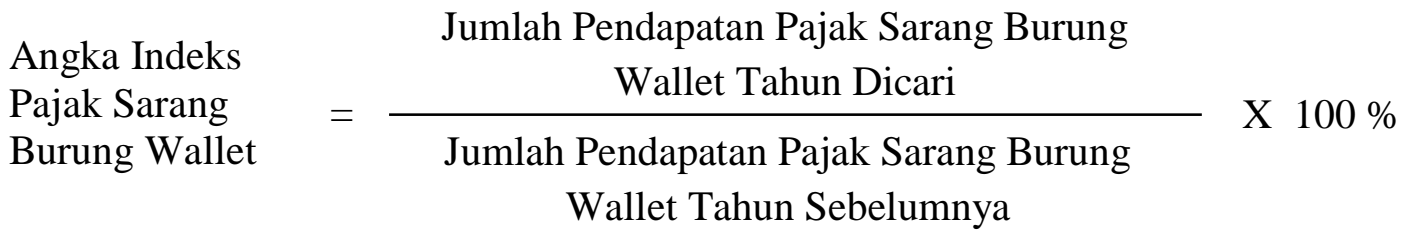

Dari hasil perhitungan angka indeks ini, dapat dilihat perkembangan jumlah pendapatan pajak sarang burung wallet selama lima tahun dimulai tahun 2015 sampai dengan tahun 2020. Berapa persen (\%) perubahan pendapatan pajak sarang burung wallet dibandingkan dengan tahun sebelumnya.

2. Dalam menjawab rumusan masalah kedua tentang bagaimana upaya meningkatkan pendapatan pajak sarang burung wallet di pemerintahan Kabupaten Murung Raya, yaitu dengan menggunakan analisis SWOT. Adapun unsur-unsur yang digunakan yaitu:

a. Strength (kekuatan)

Analisis untuk mengetahui kekuatan atau keunggulan dari pajak sarang burung wallet yang dapat dipengaruhi oleh lingkungan internal.

b. Weaknes (kelemahan)

Analisis untuk mengetahui kekurangan-kekurangan pemerintah daerah kabupaten Murung raya dalam pemungutan pajak sarang burung wallet.

c. Opportunity (Kesempatan)

Merupakan kesempatan atau peluang yang dapat memungkinkan peningkatan pendapatan pajak sarang burung wallet.

d. Threat (ancaman)

Merupakan kemungkinan yang dapat terjadi dan menghambat peningkatan pendapatan pajak sarang burung wallet.

3. Untuk menjawab rumusan masalah yang ketiga tentang prediksi pendapatan pajak sarang burung wallet untuk periode tahun 2021 sampai dengan 2026 di pemerintahan Kabupaten Murung Raya, menggunakan perhitungan peramalan dengan analisis Trend Metode Last Square - jumlah kuadrat terkecil (Budiyuwono, 1995: 211-212). Persamaan garis trend yang digunakan yaitu: $\mathrm{Y}^{1}=\mathrm{a}+\mathrm{bX}$.

Dimana:

$\mathrm{Y}^{1}=$ Nilai trend pajak sarang burung wallet

$\mathrm{X}=$ Tahun tertentu yang akan diteliti

$\mathrm{a}=$ Jumlah $\mathrm{Y}$ pada saat $\mathrm{X}=0$ atau besarnya pendapatan pajak sarang burung wallet pada tahun tengah. 
$\mathrm{b}=$ Jumlah kenaikan/penurunan pendapatan pajak sarang burung wallet pertahun.

Dengan metode Least Square, maka nilai a dan b dapat dicari dengan rumus sebagai berikut:

$a=\frac{\sum Y}{n}$

Dimana:

$\mathrm{a}=$ Jumlah $\mathrm{Y}$ pada saat $\mathrm{X}=0$ atau besarnya pajak sarang burung wallet pada tahun tengah.

$\mathrm{Y}=$ Jumlah realisasi pendapatan pajak sarang burung wallet.

$\mathrm{n}=$ Jumlah tahun yang akan diprediksi.

$b=\frac{\sum X Y}{\sum X^{2}}$

Dimana:

$\mathrm{b}=$ Jumlah kenaikan/penurunan pendapatan pajak sarang burung wallet pertahun.

$\mathrm{X}=$ Jarak antara tahun yang akan diprediksi dengan tahun tengah.

\section{Hasil Penelitian dan Pembahasan}

Untuk mengetahui perkembangan pendapatan pajak sarang burung wallet dengan menggunakan angka indeks. Angka indeks berfungsi sebagai angka perbandingan yang perubahan relatifnya dinyatakan dalam bentuk presentase terhadap yang lain, dengan memilih tahun 2015 sebagai tahun dasar. Berikut data pendapatan pajak sarang burung wallet dari tahun 2015 sampai dengan tahun 2020.

Tabel 1. Realisasi Pendapatan Pajak Sarang Burung Walet Kabupaten Murung Raya Tahun 2015 Sampai dengan Tahun 2020

\begin{tabular}{cc}
\hline Tahun & Realisasi Pendapatan Pajak Sarang Burung Walet $(\mathrm{Rp})$ \\
\hline 2015 & 19.000 .210 \\
2016 & 20.001 .233 \\
2017 & 23.232 .011 \\
2018 & 27.225 .455 \\
2019 & 25.147 .487 \\
2020 & 35.544 .448 \\
\hline
\end{tabular}

1. Angka Indek Untuk Tahun 2015

$$
\text { Angka Indeks }=\frac{\text { Pendapatan Pajak Tahun } 2015}{\text { Pendapatan Pajak Tahun } 2015} \times 100 \%
$$$$
\text { Rp 19.000.210 }
$$ 


$$
\begin{aligned}
& =\frac{\operatorname{Rp} 19.000 .210}{100 \%} \\
& =100 \%
\end{aligned}
$$

Angka indeks untuk tahun 2015 sebesar 100\% menunjukan bahwa pada tahun 2015 diasumsikan dalam keadaan normal, sehingga dijadikan sebagai tahun dasar untuk membandingkan pendapatan pajak sarang burung wallet di tahun-tahun berikutnya.

2. Angka Indek Untuk Tahun 2016

$$
\begin{aligned}
\text { Angka Indeks } & =\frac{\text { Pendapatan Pajak Tahun } 2016}{\text { Pendapatan Pajak Tahun 2015 }} \times 100 \% \\
& =\frac{\operatorname{Rp} 20.001 .233}{\operatorname{Rp} 19.000 .210} \times 100 \% \\
& =101 \%
\end{aligned}
$$

Angka indeks pada tahun 2016 sebesar 101\% menunjukan bahwa terjadi peningkatan pendapatan pajak sarang burung wallet sebesar $1 \%$ dari tahun sebelumnya yaitu tahun 2015 .

3. Angka Indek Untuk Tahun 2017

$$
\begin{aligned}
\text { Angka Indeks } & =\frac{\text { Pendapatan Pajak Tahun } 2017}{\text { Pendapatan Pajak Tahun } 2016} \times 100 \% \\
& =\frac{\operatorname{Rp} 23.320 .011}{\operatorname{Rp} 20.001 .233} \times 100 \% \\
& =102 \%
\end{aligned}
$$

Angka indeks pada tahun 2017 sebesar 102\% menunjukan bahwa terjadi peningkatan pendapatan pajak sarang burung wallet sebesar 1\% dari tahun sebelumnya yaitu tahun 2016 .

4. Angka Indek Untuk Tahun 2018

$$
\begin{aligned}
\text { Angka Indeks } & =\frac{\text { Pendapatan Pajak Tahun } 2018}{\text { Pendapatan Pajak Tahun } 2017} \times 100 \% \\
& =\frac{\operatorname{Rp} 27.255 .455}{\operatorname{Rp} 23.320 .011} \times 100 \%
\end{aligned}
$$




$$
=103 \%
$$

Angka indeks pada tahun 2018 sebesar $103 \%$ menunjukan bahwa terjadi peningkatan pendapatan pajak sarang burung wallet sebesar 1\% dari tahun sebelumnya yaitu tahun 2017 .

5. Angka Indek Untuk Tahun 2019

$$
\begin{aligned}
\text { Angka Indeks } & =\frac{\text { Pendapatan Pajak Tahun } 2019}{\text { Pendapatan Pajak Tahun } 2018} \times 100 \% \\
& =\frac{\operatorname{Rp} 25.147 .487}{\operatorname{Rp} 27.255 .455} \times 100 \% \\
& =98 \%
\end{aligned}
$$

Angka indeks pada tahun 2019 sebesar 98\% menunjukan bahwa terjadi penurunan pendapatan pajak sarang burung wallet sebesar 5\% dari tahun sebelumnya yaitu tahun 2018 .

6. Angka Indek Untuk Tahun 2020

$$
\begin{aligned}
\text { Angka Indeks } & =\frac{\text { Pendapatan Pajak Tahun } 2020}{\text { Pendapatan Pajak Tahun } 2019} \times 100 \% \\
& =\frac{\operatorname{Rp} 35.544 .448}{\operatorname{Rp} 25.147 .487} \times 100 \% \\
& =108 \%
\end{aligned}
$$

Angka indeks pada tahun 2020 sebesar 98\% menunjukan bahwa terjadi peningkatan pendapatan pajak sarang burung wallet sebesar $10 \%$ dari tahun sebelumnya yaitu tahun 2019.

Pajak daerah merupakan salah satu sumber Pendapatan Asli Daerah yang dapat diandalkan untuk membiayai penyelenggaraan pemerintahan dan pembangunan daerah. Dari beberapa macam sector pajak daerah yang dipungut, pajak sarang brung wallet masih rendah sehingga diperlukan usaha-usaha yang dapat meningkatkan pajak sarang burung. Untuk mengetahui upaya-upaya peningkatan pendapatan pajak sarang burung wallet diguakan analisis SWOT (Strenght, Weaknes, Opportunity, dan Threat). Adapun factor-faktor yang digunakan, yaitu:

1. Strength (Kekuatan)

Meskipun pendapatan pajak sarang burung di Kabupaten Murung Raya masih rendah tetapi hasil yang diperoleh dari pemungutan pajak ini dapat menunjang APBD dan menjadi slah satu andalan sumber pendapatan bagi pemerintah Kabupaten Murung Raya. 
2. Weaknes (Kelemahan)

Kurangnya sanksi tegas terhadap para wajib pajak sarang burung yang tidak taat merupakan kelemahan bagi pemerintah Kabupaten Murung Raya dalam meningkatkan pendapatan pajak sarang burung wallet.

\section{Opportunity (Kesempatan)}

Ada beberapa hal yang bias dilakukan oleh pemerintah Kabupaten Murung Raya, yaitu:

a. Peningkatan kualitas sumber daya manusia yang bertugas memungut pajakdan penyuluhan pada wajib pajak sarang burung wallet karena masih banyak pengusaha dan pengelola sarang burung yang belum memenuhi kewajiban membayar pajak.

b. Hubungan baik yang terjalin antara pemerintah kabupaten Murung Raya dengan para wajib pajak sarang burung wallet merupakan kesempatan bagi pemerintah daerah dalam meningkatkan pajak sarang burung wallet. Hubungan baik tersebut misalnya membantu menyelesaikan masalah yang dihadapi wajib pajak dengan masyarakat sekitar tempat pengelolaan sarang burung.

\section{Threat (ancaman)}

Kurangnya kesadaran masyarakat sebagai wajib pajak akan pentingnya membayar pajak dan kurangnya kepercayaan masyarakat pada pemerintah dalam pengelolaan pajak merupakan ancaman bagi pemerintah daerah dalam meningkatkan pendapatan pajaknya.

Untuk dapat mengetahui pendapatan pajak sarang burung wallet tahun 2021 sampai dengan taun 2026 di Kabupaten Murung Raya akan digunakan perhitungan permalan dengan analisis tren dengan metode Least Square dengan persamaan tren yang digunakan adalah $\mathrm{Y}=$ $\mathrm{a}+\mathrm{Bx}$.

Tren merupakan gerak naik turun dalam jangka panjang yang biasanya digambarkan dalam bentuk suau garis lurus berdasarkan data yang ada. Adapun langkah-langkah dalam perhitungan tren tersebut antara lain:

1. Menentukan nilai a dengan rumus:

$$
a=\frac{\sum Y}{n}
$$

\section{Dimana:}

$\mathrm{a}=$ Jumlah $\mathrm{Y}$ pada saat $\mathrm{X}=0$ atau besarnya pendapatan pajak pada tahun tengah

$\mathrm{Y}=$ Jumlah realisasi pendapatan pajak

$\mathrm{n}=$ Jumlah tahun yang akan diprediksi

2. Menentukan Nilai b Dengan Rumus:

$$
b=\frac{\sum X Y}{\sum X^{2}}
$$

Dimana:

$\mathrm{b}=$ Jumlah kenaikan/penurunan pendapatan pajak pertahun

$\mathrm{X}=$ Jarak antara tahun yang akan diprediksi dengan tahun tengah 
3. Menentukan persamaan garis tren dengan rumus:

$\mathrm{Y}=\mathrm{a}+\mathrm{bx}$

Dimana:

$\mathrm{Y}=$ Nilai tren Pajak

Berdasarkan table 2 diatas, maka prediksi jumlah pendapatan pajak sarang burung wallet untuk tahun 2020 sampai dengan tahu 2026 dapatdiketahui dengan perhitungan seperti pada Tabel 2.

Tabel 2. Perhitungan Tren Pajak Sarang Burung Walet Kabupaten Murung Raya Tahun 2020 Sampai Dengan 2026.

\begin{tabular}{ccccc}
\hline Tahun & $\mathrm{X}$ & $\begin{array}{c}\text { Pendapatan Pajak Sarang Burung } \\
\text { Walet }\end{array}$ & $\mathrm{X}^{2}$ & $\mathrm{XY}$ \\
\hline 2021 & -5 & 19.000 .210 & 25 & -95.001 .050 \\
2022 & -3 & 20.001 .233 & 9 & -60.003 .699 \\
2023 & -1 & 23.232 .011 & 1 & -23.232 .011 \\
2024 & 1 & 27.225 .455 & 1 & 27.225 .455 \\
2025 & 3 & 25.147 .487 & 9 & 75.442 .461 \\
2026 & 5 & 35.544 .448 & 25 & 177.722 .240 \\
\hline $\mathrm{n}=6$ & 0 & 150.150 .844 & 70 & 102.153 .396 \\
\hline
\end{tabular}

Perhitungan analisis tren pendapatan pajak sarang burung wallet adalah sebagai berikut:

1. Menentukan nlai a

$$
\begin{aligned}
a & =\frac{\sum Y}{n} \\
& =\frac{\operatorname{Rp~} 150.150 .844}{6} \\
& =\operatorname{Rp} 25.025 .141
\end{aligned}
$$

Nilai a $=$ Rp 25.025.141,- menunjukan besarnya jumlah pendapatan pajak sarang burung wallet (Y) pada tahun tengah antara tahun 2017 dan tahun 2018.

2. Menentukan nilai $\mathrm{b}$

$$
\begin{aligned}
b & =\frac{\sum X Y}{\sum X^{2}} \\
& =\frac{\operatorname{Rp~102.153.396}}{70}=\operatorname{Rp~146.000,-}
\end{aligned}
$$


Nilai $b=\operatorname{Rp} 146.000,-$ menunjukan besarnya jumlah kenaikan pendapatan pajak sarang burung wallet per tahun Rp 146.000,-.

3. Menentukan persamaan garis tren

Berdasarkan nilai a dan b yang telah dihitung pada langkah sebelumnya, maka persamaan garis tren pajak sarang burung wallet adalah:

$\mathrm{Y}=\mathrm{a}+\mathrm{bx}$

$Y=25.025 .141+146.000 X$

4. Melakukan peramalan (Forecasting) dengan menggunakan persamaan garis tren pendapatan pajak sarang burung wallet.

Berdasarkan persamaan garis tren ini, maka dapat dihitung prediksi pendapatan pajak sang burung untuk tahun-tahun yang akan datang dengan menggunakan nilai $\mathrm{X}$ yang telah disajikan di tabel 2. Prediksi pendapatan pajak sarang burung wallet pada tahun 2020 sampai dengan tahun 2026 adalah sebagai berikut:

a. Untuk tahun 2021

$$
\begin{aligned}
Y & =25.025 .141+146.000 X \\
Y & =25.025 .141+146.000(7) \\
& =26.047 .141
\end{aligned}
$$

Jumlah pendapatan pajak untuk tahun 2020 diprediksikan sebesar Rp 26.047.141,--

b. Untuk tahun 2022

$$
\begin{aligned}
Y & =25.025 .141+146.000 X \\
Y & =25.025 .141+146.000(9) \\
& =26.339 .141
\end{aligned}
$$

Jumlah pendapatan pajak untuk tahun 2021 diprediksikan sebesar Rp 26.339.141,--

c. Untuk tahun 2023

$$
\begin{aligned}
Y & =25.025 .141+146.000 X \\
Y & =25.025 .141+146.000(11) \\
& =26.631 .141
\end{aligned}
$$

Jumlah pendapatan pajak untuk tahun 2022 diprediksikan sebesar Rp 26.631.141,-- 
d. Untuk tahun 2024

$$
\begin{aligned}
Y & =25.025 .141+146.000 X \\
Y & =25.025 .141+146.000(13) \\
& =26.923 .141
\end{aligned}
$$

Jumlah pendapatan pajak untuk tahun 2023 diprediksikan sebesar Rp 26.923.141,-.

e. Untuk tahun 2025

$$
\begin{aligned}
Y & =25.025 .141+146.000 X \\
Y & =25.025 .141+146.000(15) \\
& =26.047 .141
\end{aligned}
$$

Jumlah pendapatan pajak untuk tahun 2045 diprediksikan sebesar Rp 27.215.141,-.

f. Untuk tahun 2026

$$
\begin{aligned}
Y & =25.025 .141+146.000 X \\
Y & =25.025 .141+146.000(17) \\
& =27.507 .141,-.
\end{aligned}
$$

Jumlah pendapatan pajak untuk tahun 2026 diprediksikan sebesar Rp 27.507.141,--

Perkembangan pendapatan pajak sarang burung selama 2015 sampai dengan tahun 2020 Dapat dilihat pada tabel 3.

Tabel 3. Angka Indek Pajak Sarang Burung Walet Kabupaten Murung Raya Tahun 2015 Sampai Dengan Tahun 2020

\begin{tabular}{ccc}
\hline Tahun & \multicolumn{2}{c}{ Pendapatan Pajak Sarang Burung Walet } \\
\cline { 2 - 3 } & Realisasi (Rp) & Angka Indeks \\
\hline 2015 & 19.000 .210 & $100 \%$ \\
2016 & 20.001 .233 & $101 \%$ \\
2017 & 23.232 .011 & $102 \%$ \\
2018 & 27.225 .455 & $103 \%$ \\
2019 & 25.147 .487 & $98 \%$ \\
2020 & 35.544 .448 & $108 \%$ \\
\hline
\end{tabular}

Berdasarkan tabel 3 dapat diketahui bahwa pendapatan daerah dari sektor pajak sarang burung wallet pada pemerintah Kabupaten Murung Raya mengalami peningkatan dari tahun 2015 sampai dengan tahun 2018. Pada tahun 2016 pendapatan pajak sarang burung wallet meninngkat $1 \%$ dan tahun 2017 menimgkat sekitar 2\%. Serta tahun 2018 meningkat sekitar 3\%. Namun tahun 2019 pendapatan pajak sarang burung wallet mengalami penurunan sebesar 
5\% dan pada tahun 2020 pendapatan pajak dari sektor sarang burung wallet kembali meningkat sekitar $8 \%$.

Upaya-upaya yang harus dilakukan untuk meningkatkan pendapatan pajak sarang burung wallet di Kabupaten Murung Raya antara lain:

1. Adanya Sosialisasi tentang peraturan-peraturan yang berkaitan dengann pajak sarang burung wallet dan penyuluhan bagi para pengusaha sarang burung wallet tentang pentingnya membayar pajak.

2. Adanya penawasan yang optimal bagi pihak yang berwenang dalam pengelolaan pajak.

3. Adanya sanksi tegas pada para wajib pajak yang tidak taat memnayar pajak .

4. Adanya penambahan dan perbaikan-perbaikan fasilitas umum yang dapat digunakan untuk kepentingan umum.

Prediksi pendapatan pajak sarang burung wallet pada tahun 2020 sampai dengan tahun 2026 dapat dilihat pada tabel 4.

Tabel 4. Prediksi Pendapatan Pajak Sarang Burung Walet Pemerintah Kabupaten Murung Raya Tahun 2017 Sampai Dengan Tahun 2021

\begin{tabular}{cc}
\hline Tahun & Prediksi Pendapatan Sarang Burung Walet (Rp) \\
\hline 2021 & 26.047 .141 \\
2022 & 26.339 .141 \\
2023 & 26.631 .141 \\
2024 & 26.923 .141 \\
2025 & 26.047 .141 \\
2026 & 27.507 .141 \\
\hline
\end{tabular}

Berdasarkan tabel 4 dapat dilihat bahwa jumlah pendapatan pajak sarang burung wallet di Kabupaten Murung Raya pada tahun 2021 sampai dengan tahun 2026 terus menerus mengalami peningkatan dari tahun ketahun, sehingga pajak sarag burung wallet dapat menunjang pendapatan asli daerah di Kabupaten Murung Raya. Dengan asumsi yang digunakan untuk meningkatkan pedapaan asli daerah (PAD) khususnya pajak daerah adalah potensi wajib pajak, potensi besarnya pajak yang ditetapkan, efektivitas pemungutan, tarif pajak dan dasar pengenaan pajak.

\section{Kesimpulan}

Simpulan dari hasil pembahasan penelitian adalah diketehui bahwa Perkembangan pendapatan pajak sarang burung wallet di kabupaten Murung Raya untuk tahun 2015 sampai dengan tahun 2020 telah mengalami peningkatan dan penurunan. Prediksi pendapatan pajak sarang burung wallet di Kabupaten Murung Raya pada tahun 2021 sampai dengan tahun 2026 terus menerus mengalami peningkatan dari tahun ketahun. Upaya - upaya yag diharus dilakukan untuk meningkatkan pendapatan pajak sarang burung wlet pemerintah Kabupaten Murung Raya yaitu adanya sosialisi tentang peraturan-peraturan yang berkaitan dengan pajak sarang burung wallet dan penyuluhan bagi para pengusaha sarang burung wallet tentang pentingnya membayar pajak serta adanya pengawasan yang optimal bagi yang pihak yang berwenang dalam pengelolaan pajak dan adanya sanksi bagi para wajib pajak yang tidak membayarkan pajaknya.

Adapun saran yang perlu direkomendasikan dalam penelitian ini yang berdasarkan dari hasil perhitungan angka indeks perkembangan pajak sarang burung mengalami perkembangan yang cukup signifikan. Dengan perkembangan tersebut sebaiknya pemerintah Kabupaten Murung Raya melakukan kajian dan evaluasi kembali terhadap proses dan hasil yang telah 
dicapai untuk mengetahui apakah hasil yang dicapai sudah cukup dengan pelayanan yang disediakan bagi masyarakat ataukah masih terdapat kekurangan serta keluhan-keluhan dari masyarakat yang perlu diperbaiki di tahun-tahun yang akan datang.

Untuk dapat meningkatkan pendapatan pajak dari sektor pajak sarang burung wallet pemerintah daerah dapat melakukan upaya optimalisasi secara intensif terhadap pemungutan pajak daerah terutama pajak sarang burung wallet. Hal ini dapat dilakukan dengan pemberian sanksi tegas terhadap para wajib pajak yang tidak mentaati peraturan pajak yang berlaku.

\section{DAFTAR PUSTAKA}

Budiyuwono, Nugroho. 1995. Pengantar Statistik dan Ekonomi Perusaan. Yogyakarta: UPP AMP YKPN.

Gilarso, T. 2004. Pengantar Ilmu Ekonomi Makro, Yogyakarta: Kanisius.

Kabupaten Murung Raya, Peraturan Daerah Nomor 19 Tahun 2009 tentang Pajak Pengelolaan dan Pengusahaan Sarang Burung.

Lestari, Wihelmina Shanti Eka, 2001. Analisis Perkembangan Pendapatan Pajak Daerah Tingkat II, Prediksi Pendapatan Pajak Daerah serta Kontribusi

Pendapatan Pajak Daerah. Skripsi. Yogyakarta: Universitas Sanata Dharma.

Mardiasmo. 2008. Perpajakan. Yogyakarta: Andi Offset.

Mayani, Elli. 1996. Analisis Perkembangan Pendapatan Pajak Daerah, Prediksi Pendapatan Pajak Daerah Serta Potensi Pendapatan Pajak Daerah. Yogyakarta: Universitas Sanata Dharma.

Putyatmoko,Y. Sri. 2002. Pengantar Hukum Pajak. Yogyakarta; Andi Offset.

Rangkuti, Fredd. 1997. Analisis SWOT: Teknik Membedah Kasus Bisnis. Jakarta: PT. Gramedia Pustaka Utama.

Republik Indonesia Undang-Undang Nomor 33 Tahun 2004 Tentang Perimbangan Keuangan Antara Pemerintah Pusat dan Pemerintah Daerah.

Republik Indonesia, Undang-Undang Nomor 12 Tahun 2008 tentang Pemerintahan Daerah.

Republik Indonesia, Undang-Undang Nomor 28 Tahun 2009 tentang Pajak Daerah dan Retribusi Daerah.

Waluyo. 2000. Perpajakan Indonesia. Jakarta: Salemba Empat.

Waluyo dan Wirawan B. Ilyas. 2000. Perpajakan Indonesia. Setakan Kedua. Jakarta; Salemba Empat.

Zain, Mohammad. 2008. Manajemen Perpajakan. Edisi Ketiga. Jakarta: Salemba Empat 